\title{
Nielegalny pobór gazu - ogólna charakterystyka
}

\section{Illegal gas consumption - general characteristics}

\author{
Paweł Kułaga \\ Instytut Nafty i Gazu - Państwowy Instytut Badawczy
}

\begin{abstract}
STRESZCZENIE: Rozliczeniom gazowym zawsze towarzyszy powstawanie nierozliczonych ilości gazu, które muszą być brane pod uwagę przez operatorów gazowniczych. Kradzieże gazu są jednym ze źródeł nierozliczonych ilości gazu w obszarze dystrybucji gazu i mogą obejmować nawet do kilku procent przychodów z dostawy gazu. Operator powinien posiadać skuteczne narzędzia do przeciwdziałania kradzieżom, zarówno poprzez ich wykrywanie, jak i przeciwdziałanie. Przedsiębiorstwa gazownicze starają się przeciwdziałać kradzieżom gazu i je wykrywać, stosując różne metody. Jedną z nich jest ciągła kontrola zużycia gazu w poszczególnych punktach poboru gazu. Operator gazowniczy może w ten sposób minimalizować straty gazu wynikające z użytkowania wadliwych gazomierzy oraz straty gazu powstałe w wyniku nieszczelności spowodowanych przez osoby trzecie. Zastosowanie technologii komunikacji bezprzewodowej w urządzeniach pomiarowych i połączenie gazomierzy w sieci komunikacyjne umożliwia monitorowanie gazomierzy i dynamiczne przesyłanie danych z urządzeń pomiarowych. Każda ingerencja osób niepowołanych w sieć gazową, instalację gazową czy też w układ pomiarowy może stwarzać zagrożenie dla życia i zdrowia ludzkiego, a nielegalny pobór paliwa gazowego jest zabroniony i podlega egzekucji karnej. Kwestie nielegalnego pobierania gazu zostały określone w polskim prawie przede wszystkim w ustawie Prawo energetyczne oraz w rozporządzeniach: w sprawie przeprowadzania kontroli przez przedsiębiorstwa energetyczne, w sprawie ustalenia zakresu i wysokości opłat za nielegalny pobór paliw gazowych oraz w sprawie szczegółowych warunków funkcjonowania systemu gazowego. Najpowszechniej stosowanym gazomierzem do pomiaru objętości zużywanego gazu w gospodarstwach domowych jest gazomierz miechowy, który zwykle wyposażony jest w liczydło mechaniczne, ale w ostatnim czasie coraz bardziej rozpowszechnia się stosowanie liczydeł elektronicznych. W publikacji określono kilka podstawowych rodzajów ingerencji w gazomierze miechowe domowe, w tym w układ pomiaru, w układ rejestracji, poprzez oddziaływanie magnesami neodymowymi, jak również poprzez ominięcie urządzenia pomiarowego. Najpowszechniejszymi są ingerencje poprzez uszkodzenie plomb zabezpieczających i demontaż liczydła gazomierza, a następnie zmianę wskazania lub ingerencje, które powodują fałszowanie wskazań. Zwrócono uwagę, że istotnymi czynnikami w ograniczaniu nielegalnego poboru gazu w wyniku ingerencji w urządzenia pomiarowe są skuteczna kontrola poboru gazu oraz zapewnienie właściwej konstrukcji gazomierzy, w tym wyposażenie ich w liczydło elektroniczne z komunikacją zdalną.
\end{abstract}

Słowa kluczowe: nierozliczone ilości gazu, nielegalny pobór gazu, kradzież gazu, gazomierz, gazomierz inteligentny.

ABSTRACT: Gas billing is always accompanied by unaccounted-for gas loss (UAG) which must be taken into account by gas operators. Gas theft is one of the sources of UAG in the gas distribution area and can be as high as several percent of revenues from gas supplies. The operator should have effective tools to prevent theft, both by detecting and combatting it. Gas companies try to prevent and detect gas theft using various methods. One of them is the continuous control of gas consumption at individual gas consumption points. The gas operator can thus minimize gas losses due to the use of faulty gas meters and gas losses due to leaks caused by third parties. The use of wireless communication technology in measuring devices and the connection of gas meters in smart networks enables the monitoring of gas meters and dynamic data transfer from the measuring devices. Any unauthorized interference with the gas network, gas installation or measurement system may pose a threat to human life and health, and illegal consumption of gaseous fuel is prohibited and is subject to criminal enforcement. The issues of illegal gas consumption have been defined in Polish law, first of all in the Energy Law, and in regulations concerning inspections by energy companies, on determining the scope and amount of fees for illegal consumption of gaseous fuels, and on detailed conditions for the operation of the gas system. The most widely used gas meter for measuring the volume of gas consumed in households is the diaphragm gas meter, which is usually equipped with a mechanical index, but in recent times the use of an electronic index has become more and more popular. The publication specifies several basic types of interference with household diaphragm gas meters, including the measurement system, the index, through the interaction with neodymium magnets, as well as by bypassing the measuring device. The most common are interventions by damaging the security seals and disassembling the gas meter index, followed by a change of indication or tampering resulting in false readings. It has been pointed out that the basic factor for limiting illegal gas consumption as a result of manipulation with the measuring device is ensuring the proper construction of gas meters, including equipping the gas meters with an electronic index with remote communication.

Key words: unaccounted-for gas lost, illegal gas consumption, gas theft, gas meter, smart gas meter.

Autor do korespondencji: P. Kułaga, e-mail: pawel.kulaga@inig.pl

Artykuł nadesłano do Redakcji: 11.01.2021 r. Zatwierdzono do druku: 09.04.2021 r. 


\section{Wprowadzenie}

Praktycznie we wszystkich krajach największa liczba odbiorców gazu jest podłączona do systemu dystrybucji gazu i zużywa gaz na cele komunalno-bytowe oraz produkcyjne. $Z$ tego względu największe prawdopodobieństwo nielegalnego poboru gazu występuje wśród tej grupy jego odbiorców. Co tak naprawdę kryje się pod sformułowaniem „nielegalny pobór gazu”? Definicja nielegalnego poboru gazu została określona między innymi w ustawie Prawo energetyczne (Dz.U. z 1997 r. nr 54, poz. 348 z późniejszymi zmianami). Ustawa opisuje „nielegalne pobieranie paliw lub energii" jako pobieranie paliw lub energii bez zawarcia umowy, z całkowitym albo częściowym pominięciem układu pomiarowo-rozliczeniowego lub poprzez ingerencję w ten układ mającą wpływ na zafałszowanie dokonywanych przez niego pomiarów, lub poprzez samowolną manipulację w urządzeniu regulującym obliczeniowe natężenie przepływu paliwa. Często zamiast terminu „nielegalny pobór gazu" można spotkać się z potocznym określeniem kradzieży gazu bądź w bardziej ogólnym podejściu - kradzieży energii.

W polskim systemie dystrybucji gazu jest już ponad 7,8 $\mathrm{mln}$ odbiorców domowych (GUS, 2020), którzy do rozliczeń wykorzystują gazomierze miechowe (Matusik i Jaworski, 2017; Jaworski i Dudek, 2020; Jaworski et al., 2020). Odbiorcy sektora komunalno-bytowego stanowią 97\% odbiorców końcowych gazu, zużywających około $27 \%$ całkowitej ilości gazu sprzedawanego w Polsce (Kułaga i Jaworski, 2016). Wiele krajów dostrzega problem strat związanych z kradzieżami energii (Masood, 2013; Costello, 2014; Dobó et al., 2014; Kumar et al., 2017; Ponce-Jara et al., 2017; Botev i Johnson, 2020). Rozliczeniom gazowym zawsze towarzyszy powstawanie nierozliczonych ilości gazu - UAG (unaccounted-for gas), rozumianych jako różnica pomiędzy ilością gazu dostarczonego do systemu gazowniczego a ilością gazu sprzedanego z systemu (Gacek i Jaworski, 2020). Nierozliczone ilości gazu mogą przyjmować wartości ujemne (straty gazu), jak również wartości dodatnie (tzw. superaty gazu). Wśród najważniejszych źródeł UAG można wyróżnić cztery podstawowe, a mianowicie: pomiary, księgowanie, emisje i kradzieże gazu. Najczęściej mamy do czynienia ze stratami gazu, które stanowią jeden z elementów wpływających na wynik finansowy przedsiębiorstwa, dlatego też problemem tym interesują się zarówno specjaliści gazownictwa, jak też specjaliści innych dziedzin. $Z$ technicznego punktu widzenia straty paliwa gazowego występują zawsze i można je jedynie ograniczyć, dlatego tak ważne jest precyzyjne określenie elementów składowych wpływających na straty oraz określenie miejsc (obszarów), gdzie one występują. Z wyników badań na terenie Holandii, USA, jak również prac badawczych przeprowadzonych do tej pory przez INiG - PIB (Wagner-Staszewska et al., 2007) wynika, że pomiary objętości gazu u odbiorców indywidualnych (domowych) stanowią jedną z najistotniejszych składowych nierozliczonych ilości gazu (Wagner-Staszewska i Jaworski, 2001; Jaworski, 2007). W raporcie INOGATE (2012) omówiono najistotniejsze kwestie związane z nietechnicznymi stratami gazu, czyli z objętością gazu, która nie jest rozliczana (np. w wyniku manipulacji przy gazomierzach i kradzieży gazu), oraz narzędzia stosowane przez europejskie przedsiębiorstwa gazownicze w celu zwalczania tego problemu. W przypadku jednego z największych na świecie obszarów infrastruktury dostawy gazu ziemnego w Pakistanie, o długości około 140 tys. km, szacowane nierozliczone ilości gazu UFG dla dwóch przedsiębiorstw pakistańskich (Sui Northern Gas Pipelines Limited (SNGPL) i Sui Southern Gas Company (SSGC)) wynoszą powyżej $10 \%$, podczas gdy międzynarodowy poziom odniesienia UFG wynosi 2\% (Shafiq et al., 2018). Nierozliczone ilości gazu dla SNGPL w latach 2015-2016 wyniosły 10,97\%, co daje objętościowo 4,28 miliarda stopy sześciennej (BCF) (121 $\mathrm{mln} \mathrm{m}^{3}$ ) i 2,49 miliarda PKR (rupii pakistańskich) straty finansowej (12,6 mln EUR).

Nierozliczone ilości gazu mogą przyjmować znaczne wartości, nawet do kilku procent, a kradzieże gazu generują straty gazu, które muszą być bilansowane i doliczane do taryfy, a zatem w rozliczeniu końcowym obciążają odbiorcę gazu. Straty gazu powstałe wskutek ingerencji w gazomierze oraz instalacje gazowe stanowią istotny problem w naszym kraju, a ich wielkość może osiągać nawet kilka procent przychodów pochodzących z dostawy gazu do klientów indywidualnych (Jarczyk, 2007; Gacek i Jaworski, 2014). Prawdziwa wielkość strat $\mathrm{z}$ tego tytułu nie jest znana, a ich wielkość zależy w dużym stopniu od skuteczności służb zajmujących się ich wykrywaniem. Operator powinien posiadać skuteczne narzędzia do przeciwdziałania kradzieżom, zarówno poprzez ich wykrywanie, jak i przeciwdziałanie. Określenie strat gazu utrudniają nieszczelności występujące $\mathrm{w}$ sieci i ewentualne błędy urządzeń pomiarowo-rozliczeniowych.

Przedsiębiorstwa gazownicze starają się przeciwdziałać kradzieżom gazu i je wykrywać, stosując różne metody. Jedną z nich jest ciągła kontrola zużycia gazu w poszczególnych punktach jego poboru. Porównanie odczytów z bieżącego okresu w stosunku do poprzednich okresów może być skutecznym narzędziem monitorowania strat gazu, pozwalającym zminimalizować jego skradzione ilości. Operator gazowniczy może w ten sposób również zminimalizować straty gazu powstające na wadliwych gazomierzach oraz powstałe w wyniku nieszczelności spowodowanych przez osoby trzecie (Costello, 2014). Bezpieczeństwo eksploatacji, w tym zapewnienie szczelności instalacji i urządzeń pomiarowych, staje się jeszcze bardziej istotne w kontekście planowanego wprowadzania wodoru do sieci gazowej, biorąc pod uwagę właściwości fizykochemiczne 
wodoru powodujące możliwość zwiększonego poziomu wycieku gazu przez nieszczelności (Szewczyk i Jaworski, 2020). Zagadnienia przygotowania infrastruktury gazowniczej na dodawanie wodoru do sieci gazowej zostały szerzej przedstawione między innymi w publikacjach Jaworskiego i in. (2019, 2020), Schustera i in. (2019), Huszał i Jaworskiego (2020) oraz Jaworskiego i Dudka (2020). Zastosowanie technologii komunikacji bezprzewodowej w urządzeniach pomiarowych i połączenie gazomierzy w sieci umożliwia monitorowanie gazomierzy i pozwala dynamicznie przesyłać z urządzeń pomiarowych dane takie jak natężenie przepływu gazu i ilość zużytego gazu, a także zapisywać dane w bazie danych centrum monitorowania danych (Wang i Zhang, 2013). Dzięki programom komputerowym i oprogramowaniu centrum monitorowania danych może również automatycznie analizować dane, wybierać potencjalnych odbiorców nielegalnie pobierających gaz lub kontrolować odbiorców wrażliwych, którzy dopuścili się wcześniej kradzieży gazu. Ta metoda może skutecznie zapobiegać kradzieży gazu i zmniejszać straty z nimi związane.

Metody znajdowania wadliwych gazomierzy, z zastosowaniem zintegrowanych odczytów zużycia wraz z informacjami dotyczącymi punktu poboru, takimi jak adres, klient, typ i wielkość gazomierza, zostały opisane również w publikacji Nilssona (1998). Podobne zagadnienia poruszono również w artykule Touhidiego i Davoudiego (2018), stwierdzając, że integrację danych i korzystanie z wielu źródeł danych uważa się za podstawowe zadania $\mathrm{w}$ dzisiejszych analitycznych metodach wykrywania kradzieży energii. Uzyskane wyniki oparte na proponowanym wskaźniku LI (indywidualny wskaźnik obciążenia) wskazują, że metoda może być stosowana do nadzorowania pracy małych gazomierzy jako metoda znajdowania niedokładnych gazomierzy lub instalacji, które wymagają ponownego zbadania (Nilsson, 1998). Obecnie niektóre przedsiębiorstwa użyteczności publicznej na całym świecie korzystają z funkcji smart grid (automatyczny odczyt liczników i zaawansowana infrastruktura pomiarowa) wraz z proaktywnymi analitycznymi rozwiązaniami programowymi do monitorowania i identyfikowania przypadków kradzieży gazu. Chociaż inteligentne gazomierze pomagają wykrywać kradzieże gazu, to nie są jednak do tego idealnym narzędziem. Dzieje się tak, ponieważ wiele przedsiębiorstw energetycznych wykrywa fałszywe alarmy, a także wielu klientów odkryło sprytne i skomplikowane sposoby obejścia gazomierza lub manipulacji przy nim. W świetle analizy przyczyn kradzieży gazu problemy społeczno-ekonomiczne można uznać za jedną z poważnych motywacji kradzieży gazu. Złodzieje odkrywają bardziej wyrafinowane i kreatywne sposoby kradzieży paliwa (Touhidi i Davoudi, 2018). Zwykle źródła nierozliczonych ilości gazu, jak kradzieże gazu, wadliwe lub niedziałające gazomierze, ujawniają się w rozliczeniach miesięcznych, więc należy zawsze mieć na uwadze niewyjaśnione zmniejszenia zużycia gazu dla konkretnego klienta, a także należy pamiętać, że monitorowanie zużyć, uzupełnione alertem, to najlepszy sposób na wykrycie kradzieży gazu (Metro, 2007).

Kradzieże gazu mogą mieć istotny wpływ na rachunki klientów końcowych ze względu na koszty nierozliczonych ilości gazu. Koszty związane z nierozliczonym gazem są w dużej mierze opłacane przez dostawców gazu, a później odbiorców gazu, zatem kradzież gazu ma konsekwencje finansowe dla wszystkich klientów. Szacunki wartości detalicznej skradzionej energii w przypadku operatora British Gas wahają się od 64 mln GBP do $220 \mathrm{mln}$ GBP rocznie (Wallace, 2011). Odpowiada to kwocie od 2,70 GBP do 9,80 GBP na gospodarstwo domowe rocznie. W przypadku wykrycia kradzieży dostawca może dążyć do odzyskania od klienta opłat za nielegalnie pobrany gaz wraz $\mathrm{z}$ innymi towarzyszącymi kosztami (takie jak wymiana urządzeń pomiarowo-rozliczeniowych i dochodzenie w sprawie kradzieży) (Wallace, 2011). Doświadczenia z szacowania nierozliczonych ilości gazu w sieci gazowniczej operatora Southern California Gas Company (SoCalGas) zostały szeroko omówione w serii raportów (Meshkati i Groot, 1993). Wyróżniono zarówno kradzieże w sektorze mieszkaniowym, jak też niemieszkaniowym. Analiza polegała na oszacowaniu częstości występowania kradzieży oraz objętości gazu traconego związanych z tym zjawiskiem. Omówione zostały podejścia i techniki wykrywania kradzieży i kontroli poboru gazu. Badania wykazały, że w 1991 r. kradzież wynosiła około 644,529 Mcf, w tym kradzież w mieszkaniach szacowana jest na 324,227 Mcf, a w sektorze niemieszkaniowym na 320,302 Mcf.

W przemyśle gazowniczym błędy gazomierzy generują znaczne koszty. W raporcie Instytutu Gazownictwa (GRI) (Meshkati i Groot, 1993) wskazano, że największymi źródłami UAG są błędy pomiarowe - 81,64\%, nieszczelności - 8,85\%, kradzieże gazu - 6,54\% oraz błędy księgowe - 2,97\%. Typowa sieć gazowa składa się z dużej liczby gazomierzy używanych w domach i mieszkaniach oraz z niewielkiej liczby gazomierzy o dużych zakresach pomiarowych używanych w przemyśle. Gazomierze te są często sprawdzane i dokładnie monitorowane ze względu na duże odmierzane objętości gazu. Metody stosowane do monitorowania gazomierzy przemysłowych nie mają zastosowania do mniejszych domowych gazomierzy, zarówno ze względów praktycznych, jak i ekonomicznych. Równocześnie należy stwierdzić, że kradzieże gazu nie mają istotnego znaczenia w sieciach przesyłowych ze względu na duże objętości i występujące w tych sieciach wysokie ciśnienia gazu, ale problem ten obserwuje się w niektórych sieciach dystrybucyjnych (Botev i Johnson, 2020). Kradzież gazu ziemnego, jako źródło nietechnicznych strat występujących w sieciach gazu ziemnego, powoduje poważne straty w branży energetycznej na Węgrzech. Jednym z głównych czynników są kradzieże gazu w gospodarstwach domowych. Do 2014 
roku najczęściej stosowane były gazomierze miechowe, których wewnętrzne, ruchome elementy układu pomiarowego były wykonane z materiałów ferromagnetycznych i nie były odporne na oddziaływanie magnesów trwałych przykładanych do obudowy gazomierzy. Badania remanencji magnetycznej (namagnesowania szczątkowego) posłużyły do zbadania próbki 80 gazomierzy domowych i wykrycia potencjalnych ingerencji. Na podstawie pomiaru remanencji magnetycznej $10 \%$ gazomierzy uznano za podejrzane, z czego $50 \%$ zostało potencjalnie potwierdzonych w dalszych badaniach mechanicznych. Szacuje się, że w latach 2010-2013 na Węgrzech roczna średnia strata spowodowana kradzieżami gazu ziemnego wynosiła od $10 \mathrm{mln}$ do $40 \mathrm{mln}$ USD (Dobó et al., 2014). Zagadnienia oddziaływania magnesów neodymowych były podejmowane w Pracach Instytutu Nafty i Gazu (Gacek et al., 2006, 2008). Efektem doświadczeń Instytutu było opracowanie kryteriów oceny wyników badań gazomierzy narażonych na odziaływanie magnesów (Gacek i Jaworski, 2014; Jaworski i Gacek, 2016). Bezpieczeństwo danych pomiarowych jest również istotnym aspektem projektowania urządzeń i zaawansowanych systemów pomiarowych (AMI), ponieważ dane są przesyłane na duże odległości i otwiera to możliwości powstawania luk w zabezpieczeniach związanych z kradzieżą lub manipulacją danymi, naruszając $\mathrm{w}$ ten sposób prywatność konsumenta ze względu na zwiększoną łączność, ułatwiającą gromadzenie danych osobowych. Dane użytkowników końcowych to także potencjalne obszary zagrożeń cyberbezpieczeństwa, które mogą zostać wykorzystane do niszczenia infrastruktury, kradzieży zasilania, szpiegostwa i do innych celów (Kumar et al., 2017).

\section{Konsekwencje nielegalnego poboru gazu}

Każda ingerencja osób niepowołanych w sieć gazową, instalację gazową czy też układ pomiarowy może stwarzać zagrożenie dla życia i zdrowia ludzkiego. Kradzieże gazu mogą bezpośrednio powodować narażanie innych na ryzyko utraty zdrowia lub życia i są traktowane jako przestępstwo ścigane z urzędu. To skutkuje tym, że każdy, kto zauważył kradzież gazu, ma obowiązek powiadomienia o takiej sytuacji organy ścigania. Zgodnie z ustawą Prawo energetyczne (Dz.U. z 1997 r. nr 54, poz. 348 z późn. zmianami) nielegalny pobór paliwa gazowego jest zabroniony i podlega egzekucji karnej. W przypadku stwierdzenia nielegalnego poboru paliwa gazowego przedsiębiorstwo gazownicze obciąża sprawcę opłatą naliczaną według wytycznych znajdujących się w taryfie. Dodatkowo przedsiębiorstwo energetyczne może pobierać opłatę za czynności związane ze stwierdzeniem nielegalnego poboru paliwa gazowego według stawek określonych w taryfie (np. Polska Spółka Gazownictwa). Osoby nielegalnie pobierające gaz ponoszą odpowiedzialność wynikającą z ustawy
Prawo energetyczne wraz z aktami wykonawczymi, ustawy Kodeks karny (Dz.U z 1997 r. nr 88, poz. 553), ustawy Kodeks cywilny (Dz.U. z 1964 r. nr 16, poz. 93). Jak wynika z art. 57 ust. 1 ustawy Prawo energetyczne, zgodnie z którym „w razie nielegalnego pobierania paliw lub energii przedsiębiorstwo energetyczne może: pobierać od odbiorcy, a w przypadku, gdy pobór paliw lub energii nastąpił bez zawarcia umowy, może pobierać od osoby lub osób nielegalnie pobierających paliwa lub energię opłatę w wysokości określonej w taryfie, chyba że nielegalne pobieranie paliw lub energii wynikało z wyłącznej winy osoby trzeciej, za którą odbiorca nie ponosi odpowiedzialności, albo dochodzić odszkodowania na zasadach ogólnych". Zgodnie z art. 6. ustawy Prawo energetyczne przedsiębiorstwo energetyczne wykonujące działalność gospodarczą w zakresie przesyłania lub dystrybucji paliw lub energii przeprowadza kontrolę legalności pobierania paliw lub energii, kontrolę układów pomiarowo-rozliczeniowych, dotrzymania zawartych umów oraz prawidłowości rozliczeń. Z kolei rozporządzenie Ministra Energii (Dz.U. z 2018 r. poz. 640) w $\S 43$ ust. 1 wskazuje, że ,w przypadku nielegalnego pobierania paliw gazowych przedsiębiorstwo energetyczne wykonujące działalność gospodarczą w zakresie przesyłania lub dystrybucji paliw gazowych może obciążyć odbiorcę lub podmiot nielegalnie pobierający paliwa gazowe opłatami, które są obliczane jako iloczyn trzykrotnej ceny referencyjnej paliw gazowych obowiązującej w miesiącu stwierdzenia nielegalnego poboru oraz ryczałtowych ilości energii zawartej w tych paliwach, na zasadach określonych w taryfie". Obecnie cena referencyjna gazu ustalana jest na podstawie średniej ważonej ceny zakupu paliwa gazowego przez operatora dystrybucyjnego w miesiącu gazowym poprzedzającym miesiąc gazowy, w którym jest opublikowana na stronie internetowej operatora. Zgodnie z art. 6b ust. 1 i 4 ustawy Prawo energetyczne (Dz.U. z 1997 r. nr 54, poz. 348 z późn. zmianami) przedsiębiorstwo energetyczne może wstrzymać dostarczanie paliw gazowych lub energii, jeśli w wyniku przeprowadzonej kontroli stwierdzono, że instalacja znajdująca się u odbiorcy stwarza bezpośrednie zagrożenie dla życia, zdrowia albo środowiska i/lub nastąpił nielegalny pobór paliw lub energii. $Z$ treści interpretowanych łącznie przepisów art. 3 pkt 18 oraz art. 57 ust. 1 ustawy Prawo energetyczne wynika, że aby w ogóle mówić o możliwości ustalenia opłaty dodatkowej z tytułu „kradzieży” gazu (paliwa), muszą być spełnione dwa warunki, tj.:

- musi wystąpić pobieranie paliw lub energii bez zawarcia umowy z całkowitym albo częściowym pominięciem układu pomiarowo-rozliczeniowego lub

- musi wystąpić pobieranie paliw lub energii bez zawarcia umowy poprzez ingerencję w ten układ (pomiarowo-rozliczeniowy) mającą wpływ na zafałszowanie pomiarów dokonywanych przez układ pomiarowo-rozliczeniowy. 
Należy wspomnieć o krajowych przepisach wykonawczych w postaci rozporządzeń, które bezpośrednio dotyczą zagadnień kradzieży energii. W rozporządzeniu Ministra Energii (Dz.U. z 2016 r. poz. 2166) zostały określone szczegółowe sposoby przeprowadzania przez przedsiębiorstwa energetyczne wykonujące działalność gospodarczą w zakresie przesyłania lub dystrybucji paliw lub energii kontroli legalności pobierania paliw lub energii, kontroli układów pomiarowo-rozliczeniowych, dotrzymywania zawartych umów oraz prawidłowości rozliczeń. Rozporządzenie Ministra Gospodarki (Dz.U. 2010 nr 133, poz. 891) wskazuje między innymi parametry jakościowe paliw gazowych, standardy jakościowe obsługi odbiorców oraz sposób załatwienia reklamacji. W rozporządzeniu tym określono szczegółowo prawa odbiorcy gazu do zgłaszania reklamacji i wniosków o sprawdzenie prawidłowości działania układu pomiarowego. Sposób określania opłat za nielegalny pobór gazu został podany w rozporządzeniu Ministra Finansów z dnia 31 sierpnia 1998 r. w sprawie ustalenia zakresu i wysokości opłat za nielegalny pobór paliw gazowych (Dz.U. z 1998 r. nr 118, poz. 761).

\section{Metody nielegalnego poboru gazu}

Jak wspomniano na wstępie artykułu, najpowszechniej stosowanym gazomierzem do pomiaru objętości zużywanego gazu w gospodarstwach domowych jest gazomierz miechowy. Wprowadzając pewien podział, można wyróżnić dwa zasadnicze układy w gazomierzach miechowych. Pierwszy to układ pomiaru objętości gazu zabudowany w całości wewnątrz obudowy gazomierza, w którego skład wchodzą komory pomiarowe o odkształcalnych ściankach, kanał wylotowy gazu, układ mechaniczny rozrządu (przekładni mechanicznej dźwigni i kół) przenoszący ruch komór pomiarowych na sprzęgło napędowe układu rejestracji objętości. Drugi to układ rejestracji objętości gazu, napędzający poprzez sprzęgło mechaniczne, a częściej magnetyczne, liczydło gazomierza. Najpowszechniej występująca konstrukcja liczydła ma budowę mechaniczną, bębenkową, gdzie rejestracja odbywa się poprzez obrót bębenka kontrolnego wskazującego litry, a następnie obrót kolejnych bębenków, wielokrotności litrów i metrów sześciennych. Od kilku lat stosuje się także gazomierze miechowe wyposażone w liczydło elektroniczne. Liczydło gazomierza zabudowane jest w osłonie liczydła i najczęściej zabezpieczone plombami (legalizacyjnymi, weryfikacji pierwotnej, producenta) lub może być zabezpieczone innymi środkami, np. poprzez antywłamaniową konstrukcję liczydła.

Można wyszczególnić kilka podstawowych rodzajów ingerencji w gazomierze miechowe domowe: w układ pomiaru, w układ rejestracji, poprzez oddziaływanie magnesami neodymowymi, jak również poprzez ominięcie urządzenia pomiarowego (obejście), umożliwiające pobór gazu z pominięciem gazomierza. Poniżej przedstawiono podział ingerencji wraz opisem poszczególnych ich rodzajów.

Ingerencje w układ pomiaru:

- wciśnięta/wysunięta rura wylotowa - nieszczelność wewnętrzna gazomierza na skutek wciśnięcia lub wysunięcia plastikowej rury wylotowej wewnątrz króćca wylotowego gazomierza;

- otwór w rurze wylotowej - nieszczelność wewnętrzna gazomierza spowodowana wywierconym bądź wytopionym otworem w plastikowej rurze wylotowej gazomierza;

- ingerencja w mechanizm rozrządu - ingerencja w układ pomiarowy gazomierza poprzez dostęp przez króćce gazomierza;

- elementy obce w układzie pomiarowym - ingerencja poprzez umieszczenie obcych przedmiotów wewnątrz układu pomiarowego, mających na celu jego blokowanie;

- magnes neodymowy - ingerencja w układ pomiaru za pomocą magnesu neodymowego przyłożonego do obudowy gazomierza.

Ingerencje w układ rejestracji:

- brak plomby - zdemontowana plomba legalizacyjna zabezpieczająca osłonę liczydła przed demontażem;

- uszkodzona plomba w wyniku przeciągnięcia przez uchwyt osłony liczydła;

- przecięta plomba - przecięta plomba legalizacyjna;

- nieoryginalna plomba - nieoryginalna plomba legalizacyjna;

- rozsprzęglone koła przekładni liczydła, powodujące brak rejestracji objętości gazu;

- nieoryginalne koła przekładni - podmienione koła przekładni liczydła, powodujące zaniżanie wskazań gazomierza;

- przestawianie bębenków - zmiana położenia bębenków liczydła powodująca zmianę wskazań liczydła;

- blokowanie przez wywiercony otwór w liczydle - blokowanie rejestracji objętości gazu poprzez wywiercenie otworu w osłonie liczydła i blokowanie przekładni liczydła, np. drutem stalowym;

- obce elementy w liczydle - umieszczone w obrębie liczydła obce przedmioty mające na celu hamowanie lub blokowanie rejestracji objętości gazu;

- uszkodzenia liczydła lub osłony liczydła gazomierza, np. pęknięcia, wyłamania, ślady zadrapań itp.

Najpowszechniejszymi są ingerencje poprzez uszkodzenie plomb zabezpieczających i demontaż liczydła gazomierza, a następnie zmianę wskazania lub ingerencje, które powodują fałszowanie wskazań. Na rysunkach 1 i 2 przedstawiono efekt częstych manipulacji w obrębie plomb zabezpieczających (legalizacyjnych), które mogą świadczyć o ingerencjach w układ rejestracji gazomierza. Można zauważyć ślady ponownego zaciskania plomby, jak również ślady wgnieceń 
i klejenia, które nie mogły powstać podczas normalnego użytkowania. Najczęściej po uszkodzeniu i demontażu plomby dochodzi do demontowania liczydła i cofania wskazania liczydła lub do ingerencji powodujących ograniczenie lub brak rejestracji objętości gazu.

W zależności od konstrukcji liczydła gazomierza i sposobu osadzenia okienka do odczytu wskazań możliwe jest dokonywanie ingerencji poprzez demontaż okienka i dostęp w obszar mechanizmu liczydła. Na rysunku 3 przedstawiono przykład manipulacji w okienku liczydła gazomierza w celu dostępu z zewnątrz i zmiany wskazań. W wyniku ingerencji wokół okienka liczydła powstały liczne ślady zadrapań i wgnieceń oraz doszło do pęknięcia szybki.

Na rysunkach 4 i 5 przedstawiono przykład manipulacji w liczydle gazomierza poprzez wywiercenie otworu w osłonie liczydła i dostęp z zewnątrz do mechanizmu liczydła w celu blokowania rejestracji objętości gazu. W dolnej części osłony liczydła (rys. 4) zauważono wywiercony otwór, przez który wprowadzany był drut w obręb bębenków liczydła (rys. 5).

Oczywiście dla przedstawionych powyżej przypadków nie ma całkowitej możliwości wyeliminowania możliwości ingerencji - i chyba trudno zapewnić taką konstrukcję, która byłaby odporna na każdy rodzaj manipulacji - ale najważniejsze jest to, aby w przypadku powstania ingerencji pozostawiała ona trwałe i widoczne ślady.

Innym, również dość rozpowszechnionym sposobem manipulacji jest oddziaływanie magnesami neodymowymi (np. rys. 6). Sposób ten różni się od wcześniej przedstawionych przede wszystkim tym, że nie dokonuje się bezpośrednio uszkodzeń konstrukcji gazomierza, które w łatwy sposób mogą być wykryte podczas kontroli. W zależności od konstrukcji gazomierza i zastosowanych materiałów do budowy jego układu pomiarowego oddziaływanie magnesem może powodować całkowite zablokowanie rejestracji objętości gazu przy równoczesnym poborze gazu, może również powodować zablokowanie gazomierza bez możliwości poboru gazu lub gazomierz może być całkowicie odporny na pole magnetyczne magnesów. W wyniku oddziaływania magnesami mogą pozostać na obudowie gazomierza ślady wytarć i zarysowań powłoki malarskiej, jak również może być obecny zwiększony poziom namagnesowania obudowy gazomierza. Problem ten szerzej został opisany między innymi w publikacjach: Kozłowskiego (2007), Jaworskiego i Gacka (2016), Gacka (2021) oraz pracy INiG (Gacek et al., 2008). Należy zaznaczyć, że trudno jest jednoznacznie udowodnić oddziaływanie magnesami trwałymi, jeśli w trakcie kontroli magnes nie będzie przyłożony do gazomierza. Doświadczenia INiG - PIB wskazują, że nie istnieją żadne oficjalne, zwalidowane poziomy
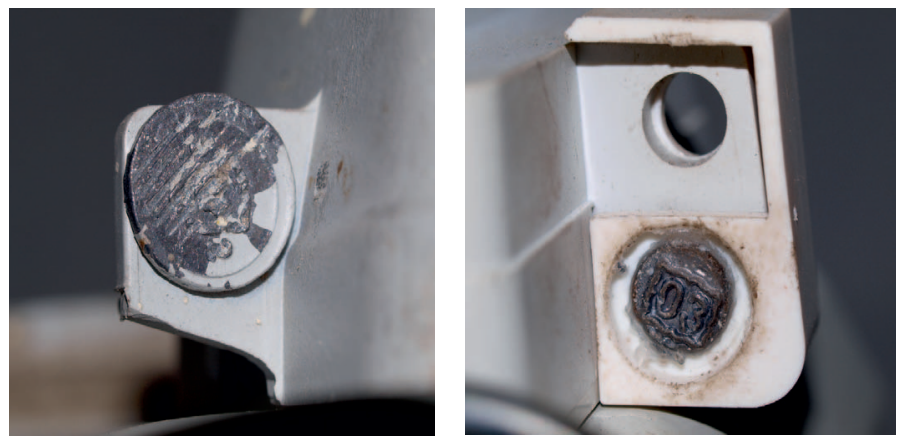

Rys. 1 i 2. Uszkodzenie plomby legalizacyjnej

Fig. 1 and 2. Damage to the verification seal

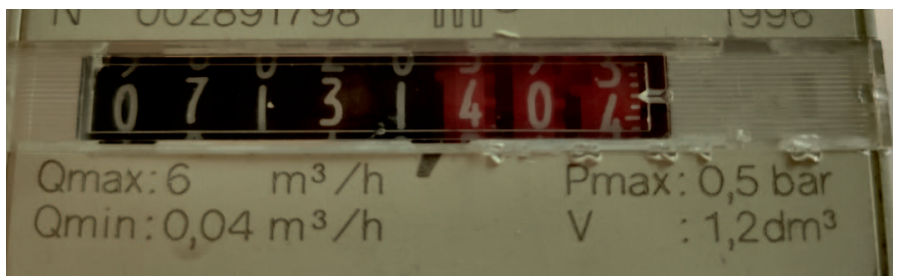

Rys. 3. Uszkodzenie okienka liczydła

Fig. 3. Damage to the index window
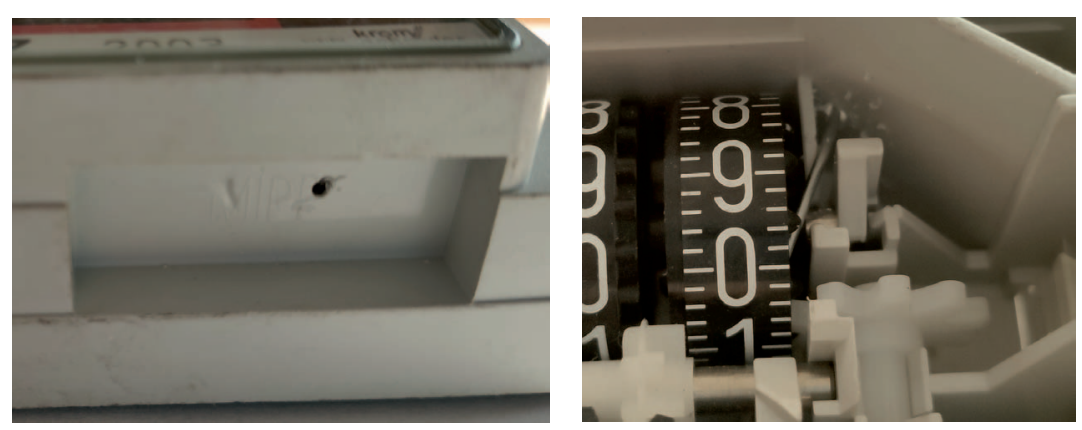

Rys. 4 i 5. Ingerencja poprzez wywiercenie otworu w osłonie liczydła i liczydle Fig. 4 and 5. Interference by drilling a hole in the index cover and index

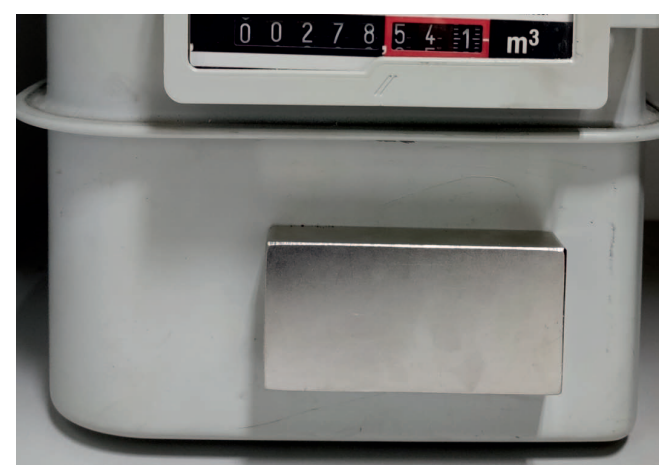

Rys. 6. Ingerencja poprzez przyłożenie magnesu trwałego do obudowy gazomierza

Fig. 6. Interference by applying a permanent magnet to the gas meter casing

namagnesowania szczątkowego obudowy, na podstawie których można potwierdzić ingerencję osób trzecich z użyciem magnesów neodymowych. Zatem wykazanie dokonywania ingerencji wyłącznie na podstawie poziomu namagnesowania 
obudowy, bez innych dodatkowych śladów wskazujących na użycie magnesów, jest bardzo trudne.

\section{Przeciwdziałanie nielegalnemu poborowi gazu}

Podstawowym czynnikiem ograniczającym nielegalny pobór gazu w wyniku manipulacji urządzeniem pomiarowym jest zapewnienie właściwej konstrukcji gazomierzy. W tym zakresie niezbędne jest spełnienie wymagań na etapie konstruowania gazomierza. Gazomierz, który będzie wykorzystywany do rozliczeń, musi przed wprowadzeniem do obrotu i użytkowania spełniać wymagania dyrektywy metrologicznej MID (Dyrektywa 2014/32/UE) oraz rozporządzeń implementujących wymagania dyrektywy w polskich przepisach. Szerzej o zasadach oceny zgodności wprowadzania przyrządów pomiarowych na rynek pisali: Tyszownicka i Jaworski (2012), Kułaga (2014), Gacek (2016). Zgodnie z załącznikiem 1 pkt 8 „Zasadnicze wymagania” dyrektywy 2014/32/UE w celu zabezpieczenia urządzeń pomiarowych przed zafałszowaniem producent musi spełnić następujące warunki:

- składniki sprzętowe, istotne dla charakterystyk metrologicznych, są tak zaprojektowane, aby można je było zabezpieczać. Przewidziane środki zabezpieczające zapewniają pozostawienie dowodu ingerencji;

- oprogramowanie istotne dla charakterystyk metrologicznych jest identyfikowane jako mające taką właściwość i zabezpieczone. Identyfikacja oprogramowania jest łatwo zapewniona przez sam przyrząd pomiarowy. Dowód ingerencji dostępny jest przez uzasadniony czas;

- dane pomiarowe, oprogramowanie istotne dla charakterystyk metrologicznych oraz ważne parametry metrologiczne przechowywane lub transmitowane są odpowiednio zabezpieczone przed przypadkowym lub celowym zafałszowaniem;

- urządzenie wskazujące przyrządu do pomiaru mediów komunalnych pokazujące całkowitą dostarczoną ilość medium lub wartości, z których taka ilość może być wyprowadzona, stanowiące w całości lub częściowo podstawę do obliczenia opłaty, nie może umożliwiać skasowania swojego wskazania w czasie użytkowania.

Zapisy dotyczące zabezpieczenia gazomierzy są podane również w normie PN-EN 1359:2004 Gazomierze miechowe, zharmonizowanej z dyrektywą metrologiczną 2014/32/UE. Zgodnie z wymaganiami gazomierz powinien być sprawdzony wizualnie, by potwierdzić, czy jest tak skonstruowany, aby jakakolwiek ingerencja mechaniczna mogąca mieć wpływ na dokładność pomiarów powodowała trwałe widoczne uszkodzenie gazomierza lub jego cechy legalizacyjnej, lub plomb. Przepisy rozporządzenia Ministra Rozwoju (Dz.U. z 2016 r. poz. 815) w sprawie wymagań dla przyrządów pomiarowych implementujące zapisy dyrektywy metrologicznej określają kluczowe wymagania konstrukcyjne, które mają zapewniać wiarygodność pomiarów i ograniczać nieuprawnione manipulacje:

- rozwiązania przyjęte w projekcie przyrządu pomiarowego w celu spełnienia wymagań muszą uwzględniać przewidywany zakres zastosowań przyrządu pomiarowego i dającą się przewidzieć każdą możliwość jego niewłaściwego użycia;

- przyrząd pomiarowy musi być tak zaprojektowany, aby był zminimalizowany wpływ uszkodzenia mogącego spowodować niedokładny pomiar, o ile wystąpienie tego uszkodzenia nie jest oczywiste;

- możliwość niewłaściwego użycia przyrządu pomiarowego musi być ograniczona;

- części składowe przyrządu pomiarowego, istotne dla charakterystyk metrologicznych, muszą być tak zaprojektowane, aby możliwe było ich zabezpieczenie przed dostępem osób nieuprawnionych, a przewidziane środki zabezpieczające zapewniały pozostawienie dowodu ingerencji. Jeden ze sposobów ograniczania kradzieży gazu oferuje rozwijający się rynek smart meteringu oraz systemów AMR (Yaacoub i Abu-Dayya, 2014). Wyposażenie gazomierza miechowego w liczydło elektroniczne z komunikacją zdalną pozwala na określenie go jako gazomierza inteligentnego (Jaworski i Dudek, 2020). System AMR wymaga zastosowania urządzeń pomiarowych zapewniających dwukierunkową zdalną komunikację i w tym kontekście należy zbadać, czy gazomierze zapewniają bezpieczne i dokładne pomiary i funkcjonalności, zwłaszcza pod kątem oddziaływania magnesami neodymowymi, ale oczekuje się równocześnie, że wprowadzenie inteligentnych liczników będzie miało pozytywny wpływ na redukcję kradzieży gazu. Po pierwsze, zastępowanie istniejących w sieci dystrybucyjnej gazomierzy spowoduje usunięcie użytkowanych zmanipulowanych gazomierzy i pomoże zidentyfikować inne osoby, które pobierają gaz z pominięciem gazomierza. Po drugie, inteligentne gazomierze mogą posiadać alarmy ostrzegające o możliwości wystąpienia kradzieży. Wreszcie bardziej szczegółowe dane dotyczące zużycia powinny umożliwić dostawcom gazu lepsze wykrywanie nieuzasadnionych przypadków zmniejszenia zużycia, wskazując wystąpienie ryzyka, że licznik nie rejestruje prawidłowo zużycia, w tym gdy może to być spowodowane kradzieżą (Wallace, 2011).

Doskonalenie konstrukcji gazomierzy, w tym zabezpieczenia plomb, zmiany osłon, zabezpieczenia przed przepływem wstecznym, zabezpieczenia przez magnesami neodymowymi czy wyposażenie w liczydła elektroniczne z zabezpieczeniami przed ingerencją mechaniczną i elektroniczną, z pewnością przyniosło w perspektywie czasu znaczące ograniczenia występowania ingerencji. Wszelkiego rodzaju zabezpieczenia, np. 
plomby na elementach podłączenia gazomierzy do instalacji gazowej, ograniczają możliwości ingerencji i poprawiają bezpieczeństwo użytkowania paliwa gazowego oraz bezpieczeństwo instalacji gazowych. Ujednolicenie zasad zabezpieczania układów pomiarowych i ustalone warunki montażu w znacznym stopniu pomagają w monitorowaniu kradzieży. Ważnymi działaniami mającymi na celu ograniczenie nielegalnego poboru gazu są: lokalizacja gazomierzy w sposób zabezpieczający przed dostępem osób niepowołanych, np. poza lokalami mieszkalnymi w zabezpieczonych szafkach gazowych, oraz skuteczna kontrola w trakcie odczytów wskazań. Ostatecznie także pewne działania regulacyjne mogą być podejmowane przez przedsiębiorstwo energetyczne, zgodnie z ustawą Prawo energetyczne. Przedsiębiorstwo energetyczne może zainstalować przedpłatowy układ pomiarowo-rozliczeniowy służący do rozliczeń za dostarczane paliwa gazowe, energię elektryczną lub ciepło na zasadach opisanych w artykule 6a w przypadku zwlekania z zapłatą za pobrane paliwo, w przypadku bezprawnego użytkowania nieruchomości lub w przypadku uniemożliwienia cyklicznego sprawdzania stanu układu pomiarowo-rozliczeniowego. W razie braku zgody odbiorcy na zainstalowanie układu pomiarowo-rozliczeniowego przedsiębiorstwo energetyczne może wstrzymać dostarczanie energii elektrycznej lub rozwiązać umowę sprzedaży energii.

\section{Podsumowanie}

Rozliczeniom gazowym zawsze towarzyszy powstawanie nierozliczonych ilości gazu. Jednym ze źródeł nierozliczonych ilości gazu są kradzieże gazu, mogące na niektórych rynkach powodować znaczące straty finansowe. Należy podkreślić, że każda ingerencja osób niepowołanych w sieć gazową czy instalację gazową, w tym w układ pomiarowy, może stwarzać zagrożenie dla życia i zdrowia ludzkiego. Monitorowanie zużycia gazu w poszczególnych punktach jego poboru może być skutecznym narzędziem do ograniczania strat gazu oraz wykrywania i minimalizowania kradzieży gazu. Pomocne mogą być tutaj wprowadzanie gazomierzy inteligentnych i stosowanie automatycznego odczytu wraz z zaawansowaną infrastrukturą pomiarową. Przedsiębiorstwa energetyczne w zakresie wykrywania, zbierania i zabezpieczania dowodów oraz egzekwowania należności za nielegalny pobór gazu stosują przede wszystkim przepisy ustawy Prawo energetyczne oraz rozporządzeń i mogą obciążać sprawcę nielegalnego poboru paliwa gazowego opłatą określoną w Taryfie dla ustug dystrybucyjnych paliwa gazowego i ushug regazyfikacji skroplonego gazu ziemnego. Zastępowanie znajdujących się w użytkowaniu gazomierzy spowoduje usunięcie zmanipulowanych gazomierzy i pomoże zidentyfikować odbiorców nielegalnie pobierających gaz. Doskonalenie konstrukcji gazomierzy, w tym zabezpieczenia plomb, zmiany osłon, zabezpieczenia przed magnesami neodymowymi czy wyposażenie w liczydła elektroniczne z zabezpieczeniami przed ingerencją mechaniczną i elektroniczną, również w perspektywie czasu ograniczy występowanie kradzieży gazu.

\section{Literatura}

Botev L., Johnson P., 2020. Applications of statistical process control in the management of unaccounted for gas. Journal of Natural Gas Science and Engineering, 76: 103194. DOI: 10.1016/j. jngse.2020.103194.

Costello K.W., 2014. Lost and unaccounted-for gas: Challenges for public utility regulators. Utilities Policy, 29: 17-24. DOI: 10.1016/j.jup.2014.04.003.

Dobó Z., Kovács H., Tóth P., Palotás A.B., 2014. Investigation of natural gas theft by magnetic remanence mapping. Forensic Science International, 245: 1-6. DOI: 10.1016/j.forsciint.2014.09.020.

Gacek Z., 2016. Ocena zgodności przyrządów pomiarowych na podstawie specyfikacji zharmonizowanych (normy EN i zalecenia OIML) oraz innych dokumentów. Nafta-Gaz, 4: 262-270. DOI: 10.18668/NG.2016.04.05.

Gacek Z., 2021, Wpływ magnesów neodymowych na pomiar paliwa gazowego gazomierzami miechowymi. Nafta-Gaz, 12: 48-56, DOI: 10.18668/NG.2021.01.06.

Gacek Z., Jaworski J., 2014. Próba wytypowania potencjalnych źródeł nielegalnego poboru gazu w sieci dystrybucyjnej gazu wśród klientów indywidualnych. Gaz, Woda i Technika Sanitarna, 12: 463-467.

Gacek Z., Jaworski J., 2020. Optimisation of measuring system construction in the context of high flow variability. Journal of Natural Gas Science and Engineering, 81: 103447. DOI: 10.1016/j. jngse.2020.103447.

Gacek Z., Jaworski J., Urban Z., Wojtala J., 2006. Badania wpływu magnesów neodymowych na dokładność pomiaru gazomierzy miechowych. Praca INiG, nr zlec. 1123/GM/2006, Archiwum Instytutu Nafty i Gazu - Państwowego Instytutu Badawczego, Kraków.

Gacek Z., Kułaga P., Urban Z., Wojtala J., 2008. Budowa stanowiska i opracowanie metodyki badawczej w celu wykonywania ekspertyz gazomierzy miechowych pod kątem nielegalnego poboru gazu ze szczególnym uwzględnieniem oddziaływania pola magnetycznego magnesów neodymowych. Praca INiG, nr zlec. 62/GM/2008, Archiwum Instytutu Nafty i Gazu - Państwowego Instytutu Badawczego, Kraków.

GUS, 2020. Gospodarka energetyczna i gazownictwo w Polsce w 2019 r. <https://stat.gov.pl/obszary-tematyczne/srodowiskoenergia/energia/ $>$

Huszał A., Jaworski J., 2020. Studies of the Impact of Hydrogen on the Stability of Gaseous Mixtures of THT. Energies, 13(23): 6441. DOI: 10.3390/en13236441.

INOGATE, 2012. SEMISE Ad Hoc Expert Facility Report. Reduction of Non-technical Natural Gas Losses in Transmission Gas Pipelines System and Gas Distribution Network.

Jarczyk D., 2007. Nierozliczone ilości gazu - Strefy dystrybucyjne - wsparcie w procesie wykrywania strat paliwa gazowego w Spółce pełniącej rolę operatora systemu dystrybucyjnego. Materiały konferencyjne „,Nierozliczone ilości gazu - wyznaczanie i metody ograniczania strat”, Gdynia, 17-19.10.2007.

Jaworski J., 2007. Pomiary dla klientów indywidualnych - nierozliczone ilości gazu - analiza i optymalizacja. Materiaty konferencyjne „Nierozliczone ilości gazu - wyznaczanie i metody ograniczania strat”, Gdynia, 17-19.10.2007. 
Jaworski J., Dudek A., 2020. Study of the Effects of Changes in Gas Composition as Well as Ambient and Gas Temperature on Errors of Indications of Thermal Gas Meters. Energies 2020, 13(20): 5428. DOI: $10.3390 /$ en 13205428.

Jaworski J., Gacek Z., 2016. Badania wpływu magnesów neodymowych na dokładność pomiaru gazomierzy miechowych. Gaz, Woda i Technika Sanitarna, 12: 438-444. DOI: 10.15199/17.2016.12.1.

Jaworski J., Kukulska-Zając E., Kułaga P., 2019. Wybrane zagadnienia dotyczące wpływu dodatku wodoru do gazu ziemnego na elementy systemu gazowniczego. Nafta-Gaz, 10: 625-632. DOI: 10.18668/NG.2019.10.04

Jaworski J., Kułaga P., Blacharski T., 2020. Study of the Effect of Addition of Hydrogen to Natural Gas on Diaphragm Gas Meters. Energies, 13(11): 3006. DOI: 10.3390/en13113006.

Kozłowski A,. 2007. Metodologia ograniczania zaniżania wskazań poboru gazu wywołanych wykorzystaniem magnesów neodymowych. Materiały konferencyjne Izby Gospodarczej Gazownictwa, Gdynia 17-19.10.2007.

Kułaga P., 2014. Ocena zgodności gazomierzy inteligentnych w świetle wymagań dyrektywy metrologicznej. Nafta-Gaz, 6: 375-382.

Kułaga P., Jaworski J., 2016. Wyniki badań trwałości gazomierzy miechowych uzyskiwane $\mathrm{z}$ zastosowaniem różnych metodyk analiza porównawcza. Nafta-Gaz, 8: 645-650. DOI: 10.18668/ NG.2016.08.09.

Kumar V.S., Prasad J., Samikannu R., 2017. Overview, issues and prevention of energy theft in smart grids and virtual power plants in Indian context. Energy Policy, 110: 365-374. DOI: 10.1016/j. enpol.2017.08.032.

Masood A., 2013. Pakistan's Gas Crisis due to Gas Theft ... \& Unaccounted for Gas (UFG). International Journal of Renewable Energy Technology Research, 2(2): 53-58. ISSN: 2325-3924.

Matusik J., Jaworski J., 2017. Optymalny dobór gazomierzy miechowych przez operatora systemu gazowniczego. Nafta-Gaz, 4: 274-286. DOI: 10.18668/NG.2017.04.08.

Meshkati S., Groot J., 1993. A study of the 1991 unaccountedfor gas volume at the Southern California Gas Company. $I-V$. GRI-93/0l15

Metro P., 2007. Technical Losses in Natural Gas Transportation, Distribution, and Storage. Presentation to the Energy Agency of the Republic of Serbia. $<$ https://pubs.naruc.org/pub.cfm?id=538EB66D2354-D714-51CD-86E3D5DC7824> (dostęp: 14.11.2020).

Nilsson U.R.C., 1998. A new method for finding inaccurate gas flow meters using billing data: Finding faulty meters using billing data. Flow Measurement and Instrumentation, 9: 237-242. DOI: 10.1016/S0955-5986(98)00026-0.

Polska Spółka Gazownictwa. Nielegalny pobór gazu. <https://www. psgaz.pl/nielegalny-pobor-gazu> (dostęp: 14.11.2020).

Ponce-Jara M.A., Ruiz E., Gil R., Sancristóbal E., Pérez-Molina C., Castro M., 2017. Smart Grid: Assessment of the past and present in developed and developing countries. Energy Strategy Reviews, 18: 38-52. DOI: 10.1016/j.esr.2017.09.011.

Schuster T., Holewa-Rataj J., Kukulska-Zając E., 2019. Ocena jakości paliw gazowych w kontekście wprowadzania wodoru do sieci gazu ziemnego. Gaz, Woda i Technika Sanitarna, 2: 42-46. DOI: 10.15199/17.2019.2.1

Shafiq M., Bin Nisar Waqas, Savino M.M., Rashid Z., Ahmad Z., 2018. Monitoring and controlling of unaccounted for gas (UFG) in distribution networks: A case study of Sui Northern Gas Pipelines Limited Pakistan. IFAC-PapersOnLine, 51(11): 253-258. DOI: 10.1016/j.ifacol.2018.08.284.

Szewczyk P., Jaworski J., 2020. Analiza wpływu dodatku wodoru do gazu ziemnego na szczelność połączeń mechanicznych wybranych elementów sieci i instalacji gazowych. Prace Naukowe
Instytutu Nafty i Gazu - Państwowego Instytutu Badawczego, 231: 1-134. DOI: 10.18668/PN2020.231.

Touhidi S., Davoudi I., 2018. Spatial Analysis Applied for Gas Theft Modelling in Tabriz City, Iran. Journal of Geoscience and Environment Protection, 6(2): 1-19. DOI: 10.4236/ gep.2018.62001.

Tyszownicka M., Jaworski J., 2012. Wybrane problemy systemu oceny zgodności i prawnej kontroli metrologicznej na przykładzie gazomierzy i przeliczników. Nafta-Gaz, 12: 1030-1035.

Wagner-Staszewska T., Jaworski J., 2001. Wpływ temperatury otoczenia na nierozliczone ilości gazu u indywidualnych odbiorców gazu. Nafta-Gaz, 11: 620-626.

Wagner-Staszewska T., Jaworski J., Gacek Z., 2007. Wybrane problemy rozliczania zużycia gazu przez indywidualnych odbiorców. Prace Instytutu Nafty i Gazu, 144: 1-98.

Wallace A., 2011. Tackling gas theft. <https://www.ofgem.gov.uk/ ofgem-publications/39192/gas-theft-consultation-112-11.pdf $>$ (dostęp: 14.11.2020).

Wang J., Zhang W.Y., 2013. A New Method to Prevent Stealing Gas in a Natural Gas Supply System. Petroleum Science and Technology, 31(20): 2065-2073. DOI: 10.1080/10916466.2011.561263.

Yaacoub E., Abu-Dayya A., 2014. Automatic meter reading in the smart grid using contention based random access over the free cellular spectrum. Computer Networks, 59: 171-183. DOI: 10.1016/j. bjp.2013.10.009.

\section{Akty prawne i dokumenty normatywne}

Dyrektywa Parlamentu Europejskiego i Rady 2014/32/UE z dnia 26 lutego 2014 r. w sprawie harmonizacji ustawodawstw państw członkowskich odnoszących się do udostępniania na rynku przyrządów pomiarowych (wersja przekształcona) (Dz.Urz. UE L 96 z 29 marca 2014 r.).

PN-EN 1359:2004 Gazomierze miechowe.

Rozporządzenie Ministra Energii z dnia 15 marca 2018 r. w sprawie szczegółowych zasad kształtowania i kalkulacji taryf oraz rozliczeń w obrocie paliwami gazowym (Dz.U. z 2018 r. poz. 640).

Rozporządzenie Ministra Energii z dnia 15 grudnia 2016 r. w sprawie przeprowadzania kontroli przez przedsiębiorstwa energetyczne (Dz.U. z 2016 r. poz. 2166).

Rozporządzenie Ministra Finansów z dnia 31 sierpnia 1998 r. w sprawie ustalenia zakresu i wysokości opłat za nielegalny pobór paliw gazowych (Dz.U. z 1998 r. nr 118, poz. 761).

Rozporządzenie Ministra Gospodarki z dnia 2 lipca 2010 r. w sprawie szczegółowych warunków funkcjonowania systemu gazowego (Dz.U. z 2010 r. nr 133, poz. 891).

Rozporządzenia Ministra Rozwoju z dnia 2 czerwca 2016 r. w sprawie wymagań dla przyrządów pomiarowych (Dz.U. z 2016 r. poz. 815).

Ustawa z dnia 10 kwietnia 1997 r. - Prawo energetyczne (Dz.U. z 1997 r. nr 54, poz. 348) z późniejszymi zmianami.

Ustawa z dnia 23 kwietnia 1964 r. - Kodeks cywilny (Dz.U. z 1964 r. nr 16, poz. 93).

Ustawa z dnia 6 czerwca 1997 r. - Kodeks karny (Dz.U. z 1997 r. nr 88, poz. 553).

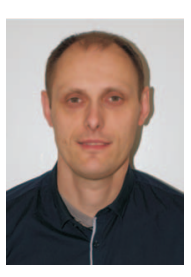

Mgr inż. Paweł KUŁAGA

Starszy specjalista badawczo-techniczny; kierownik Zakładu Metrologii Przepływów Instytut Nafty i Gazu - Państwowy Instytut Badawczy ul. Lubicz $25 \mathrm{~A}$

31-503 Kraków

E-mail:pawel.kulaga@inig.pl 